\title{
1. Títol:
}

\section{Un cas: la prevenció de lesions}

\section{Continguts teòrico-pràctics. Cas a resoldre}

L' esquinç del cap mitjà del bessó (fig. 1), és anomenat de vegades "cama de tennista" a causa de la seva alta incidència entre els esportistes.

El pacient J.B. ha sentit, en el moment de la lesió, un cop ("crac"), una punyalada, o un esclat dolorós $i$ agut a la part posterior de la cama. Aquest estrip, analitzat acuradament, no és l'esquinç del tendó d'Aquiles, que causa dolor en la porció mitjana de la part inferior del panxell.

Aquest esquinç del cap mitjà es podria haver diagnosticat de forma precoç, ja que es pot notar un defecte palpable a la part immediatament inferior al cos muscular. La comparació de les dues cames mostra el cos mitjà del bessó lesionat, desplaçat aproximadament fins a 2,5 cm.

Aquesta lesió es dóna sovint entre els esportistes amateurs, com ara els jugadors de futbol, les ballarines, i els corredors.

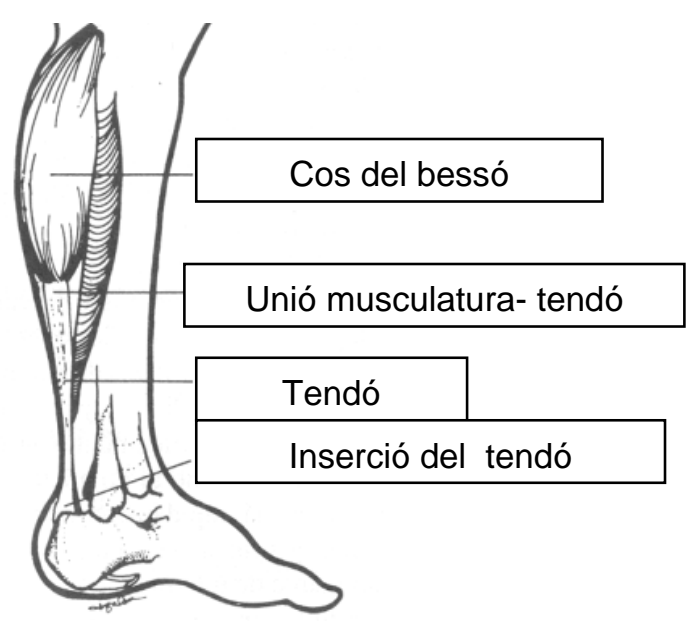

Figura 1

\section{Objectiu de l'estudi del cas}

Trobar una proposta de força per donar elasticitat amb l'estirament corresponent a la musculatura del bessó i evitar lesions d'aquest tipus.

Inserir o dibuixar una imatge que doni informació de com aplicar la força de l'estirament que heu escollit

\section{Material. Esquema}

Informació disponible a la xarxa

http://www.estiramientos.es/ i webs relacionades

http://tec.fctarc.org/estiramientos.pdf (recull 82 estiraments)

http://www.youtube.com/watch?v=oM7DADETvrQ a partir del minut 2:50

http://www.euskalnet.net//mpipaon/lesiones/lesiones/lesiones.htm lesions esportives

Agrupació: Treball en grups de 3 alumnes 


\section{Solució del cas}

Estirament per a la prevenció d'aquesta lesió diferent dels treballats a la sessió anterior.

Descriure amb totes les components el vector força que cal aplicar (utilitza i concreta aquí una escala per representar el valor de la força en $\mathrm{N} / \mathrm{cm}$ ) amb una imatge o dibuix de l'estirament.

\begin{tabular}{|l|}
\hline Punt d'aplicació \\
Direcció \\
Ventit \\
Escalor
\end{tabular}

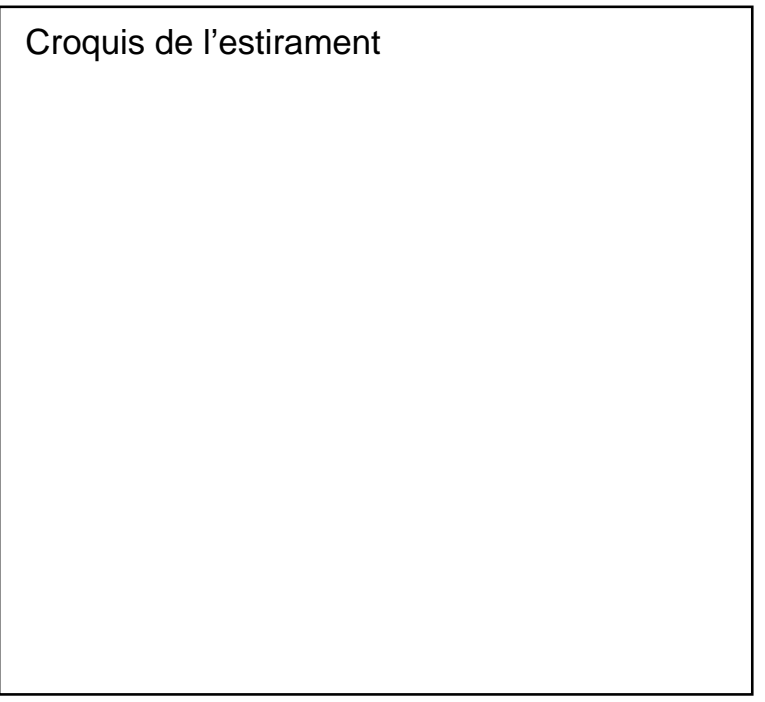

\section{Verificació i millora}

Contrastar les propostes per al cas estudiat pels diferents grups.

Escriure aquí la proposta definitiva. 